\title{
Galls on Brazilian ferns: new records and notes
}

\author{
R. P. Farias ${ }^{a}$ (D), V. L. Silva** (D), F. Gonzattic (D), L. V. Lima ${ }^{d}$ (D), J. L. Schmitt \\ and M. G. Santos ${ }^{f}$
}

${ }^{a}$ Laboratório de Pteridófitas, Universidade Federal de Pernambuco - UFPE, Rua Prof. Nelson Chaves, s/n, Cidade Universitária, CEP 50670-420, Recife, PE, Brasil

'Laboratório de Acarologia, Universidade do Vale do Taquari - Univates, CEP 95914-014, Lajeado, RS, Brasil

'Herbário da Universidade de Caxias do Sul, Rua Francisco Getúlio Vargas, 1130, Petrópolis, CEP 95070-560, Caxias do Sul, RS, Brasil

dUniversidade Federal de Minas Gerais - UFMG, Av. Presidente Antônio Carlos, 6627, Pampulha, CEP 31270-901, Belo Horizonte, MG, Brasil

'Laboratório de Botânica, Universidade Feevale - Feevale, ERS-239, 2755, CEP 93525-075, Novo Hamburgo, RS, Brasil ${ }^{\mathrm{f}}$ Faculdade de Formação de Professores, Universidade do Estado do Rio de Janeiro - UERJ, Rua Dr. Francisco Portela, 1470, Patronato, CEP 24435-005, São Gonçalo, RJ, Brasil

*e-mail: suicinivleao@gmail.com

Received: September 26, 2018 - Accepted: December 6, 2018 - Distributed: February 28, 2020

(With 5 figures)

Galls are abnormal growths of plant tissues generated from processes of hyperplasia and cellular hypertrophy, induced especially by insects and mites (detailed definition in Raman, 2007). Galls on ferns (i.e. seedless vascular plants) have been neglected in many inventories worldwide. In consequence, basic information such as the identity of gall host ferns, the frequency and locations of the interaction are still poorly known. Until present, only 16 fern species have been recorded as galls hosts in Brazil (see synopsis in Santos and Maia, 2018). In this note, we catalog ten ferns hosting galling agents, including four new records of galls, and report new locations to some ferns recorded as hosts, and characterize the morphology of the galls.

The study was conducted in five sites along the Atlantic Forest and Cerrado domain, situated in Southern and Southeastern Brazil: I - National Forest of São Francisco de Paula, municipality of São Francisco de Paula, Rio Grande do Sul State (29²5'28'S, 50²3'08'W, 906 m); II - Cambará site, municipality of Cambará do Sul, Rio Grande do Sul State (29॰10'29'S, 5001'58'W, 996 m); III - Serra da Bocaina National Park, municipality of São José do Barreiro, São Paulo State (2244'03”'S, 44³6'59”W, $1.520 \mathrm{~m})$; IV - Serra do Tabuleiro, municipality of São Bonifácio, Santa Catarina State (2749'01'S, 48 53'53”W, $1.165 \mathrm{~m})$; and V - Ibitipoca State Park, municipality of Santa Rita do Ibitipoca, Minas Gerais State $\left(21^{\circ} 42^{\prime} 32^{\prime}\right.$ 'S, 4353'38'W, $1.345 \mathrm{~m}$ ). All sites occur in highlands (800-1800 m.a.s.1.) and belong to Araucaria Forest (sites I, II and III), Rainforest (site IV) and "Campos Rupestres" (site V) phytogeography formations. The climatic conditions among the sites I, II, III and IV are the same, presenting annual rainfall above $2.400 \mathrm{~mm}$, with the hottest month $\leq 22{ }^{\circ} \mathrm{C}$ and normally with occurrence of 20-30 frozen days a year, mild summers without a dry season (Type Cfb, Peel et al., 2007). At site V, the mean annual rainfall is over $2.000 \mathrm{~mm}$, with the temperature of the hottest month $\geq 22^{\circ} \mathrm{C}$, no occurrence of frozen days, dry winters and hot summers (Type Cwb, Peel et al., 2007). Eight collections were carried out between 2017 and 2018. The names of the authors of the ferns species were abbreviated according with the website Flora do Brasil 2020. All gall morphotypes were photographed and collected. Gall shapes were standardized in accordance with Isaias et al. (2013).

The ten host ferns here cataloged are represented by three families (Gleicheniaceae, Hymenophyllaceae and Polypodiaceae) and five genera (Dicranopteris, Hymenophyllum, Campyloneurum, Niphidium and Pleopeltis, Table 1). Dicranopteris nervosa (Figure 1A, B), D. rufinervis (Figure 2A, B), H. plumosum (Figure 3G, H) and H. rufum (Figure 4A, B) are registered as gall hosts for the first time. The other two records to Hymenophyllum fill the gap on the geographic distribution, not recorded in the seminal work performed by Houard (1933). The records of N. crassifolium (Figure 5A, B), C. nitidum (Figure 5C, D) and $P$. hirsutissima (Figure 5E, F) presented here were first obtained from tropical rain forests of Rio de Janeiro State (Santos and Maia, 2018), representing new locations to these gall host ferns. The galls observed in H. pulchellum (Figure 4C-F) and H. hirsutum (Figure 3A-F) were recorded in two locations in the South and Southeast region of São Paulo and Rio Grande do Sul States (Table 1). The latter gall morphotypes were reported in Brazil by Houard (1933), without details on geographic distribution.

The morphological characterization demonstrated the occurrence of leaf galls on all host ferns (Table 1, Figure 1-5). In the case of Hymenophyllum species, leaf galls occur on both the blade and the petiole (Table 1). In addition, Hymenophyllum galls also occurred in the stems (i.e. rhizome) as reported to other epiphytic ferns: Microgramma squamulosa (Kaulf.) de la Sota (Kraus et al., 1993) and M. vaccinifolia (Langsd. \& 
Fisch.) Copel. (Maia and Santos, 2011, 2015). Galls in the leaves and stems of $H$. pulchellum and $H$. rufum do not seem to present a different morphology (Figures 3 and 4).
Houard (1933) also recorded galls on leaves and stems of $H$. pulchellum. This ability of the gall inducers to manipulate different organs in the same plant is occasionally
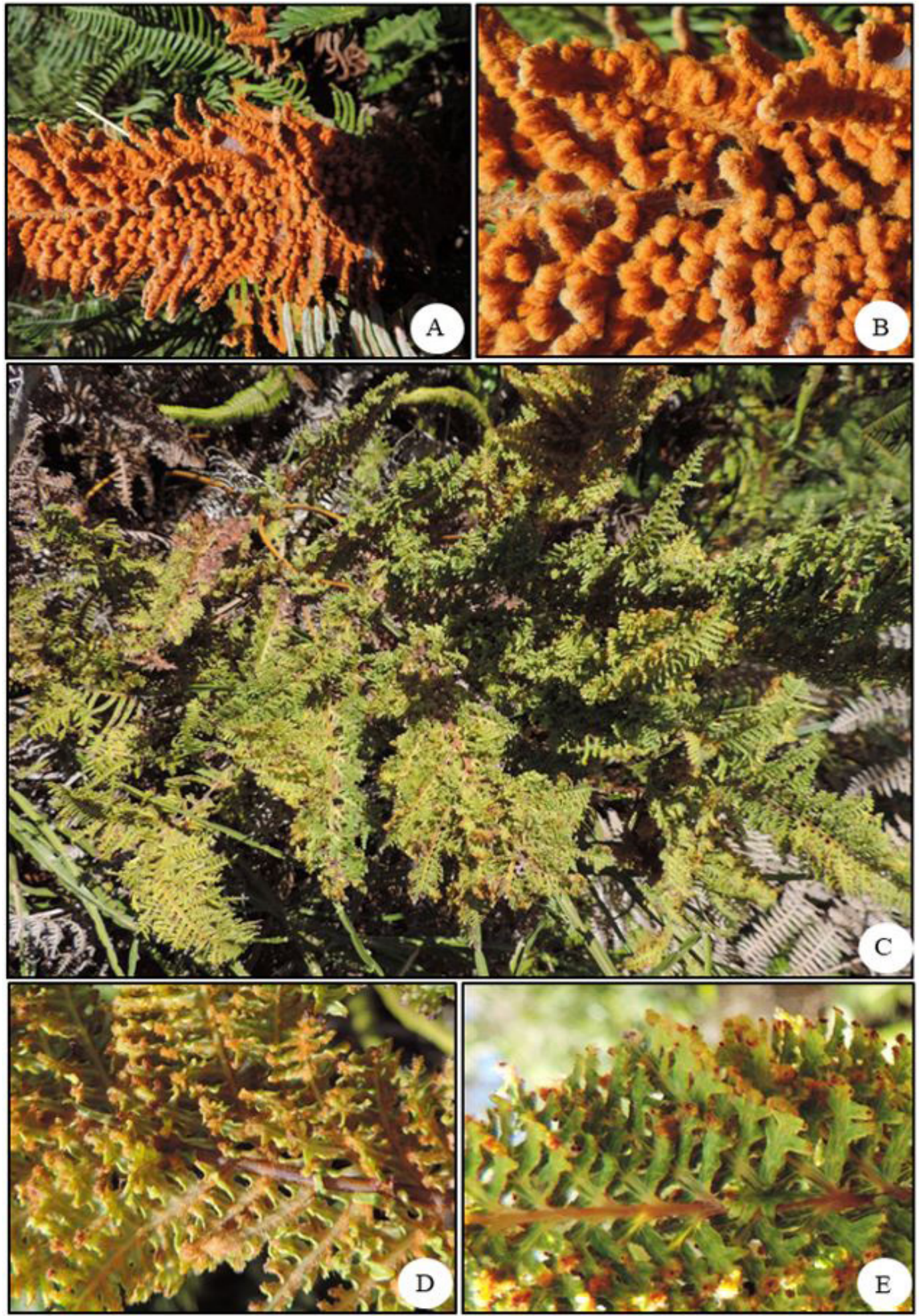

Figure 1. Galls on Gleicheniaceae family. Dicranopteris nervosa, (A, B) leaf gall. Dicranopteris flexuosa; (C-E) leaf gall. 
reported for angiosperms (e.g. Maia and Oliveira, 2010). The predominance of galls on leaves is a common pattern of this plant-insect interaction, attributed to the greater abundance of nutrients and resources in this organ (Mani, 1964). In fact, the guild diversification of gallers has shown to be influenced by leaf variability, ranging from coriaceous leaves in semi-arid zones (e.g. Carvalho-Fernandes et al., 2012), to the typically one-cell thick and few-centimeter long membranous leaves of filmy ferns (see Gonzatti and Windisch, 2018). Interestingly, in H. pulchellum, the galls are close to tuffs of leaves (Figure 4C-E), which may be a source of nutrients to galling or only an error in the manipulation of plant systems. In Gleicheniaceae, galls induce a complete modification of leaf shape, the "witches' broom" (Table 1), already described by Santos and Maia (2018) on D. flexuosa (Figure 1C-E) in Rio de Janeiro

Table 1. Records of host ferns species of galling from sites in southern-southern Brazil, and gall morphology.

\begin{tabular}{|c|c|c|c|c|}
\hline Host plant (Ferns) & Organ with gall & Gall shape & Trichomes & Sites \\
\hline \multicolumn{5}{|l|}{ Gleichenieaceae } \\
\hline $\begin{array}{l}\text { Dicranopteris flexuosa (Schrad.) } \\
\text { Underw. }\end{array}$ & Leaf & $\begin{array}{l}\text { "Witches' broom" } \\
\text { (amorphous) }\end{array}$ & - & III, IV \\
\hline Dicranopteris nervosa (Kaulf.) Maxon * & Leaf & $\begin{array}{l}\text { "Witches' broom" } \\
\text { (amorphous) }\end{array}$ & Present & III, IV \\
\hline $\begin{array}{l}\text { Dicranopteris rufinervis (Mart.) } \\
\text { Ching* }\end{array}$ & Leaf & $\begin{array}{c}\text { "Witches' } \\
\text { broom"(amorphous) }\end{array}$ & Present & $\mathrm{V}$ \\
\hline \multicolumn{5}{|l|}{ Hymenophyllaceae } \\
\hline Hymenophyllum hirsutum (L.) Sw. & Leaf & Lenticular & Present & II, III \\
\hline Hymenophyllum plumosum Kaulf. * & Leaf & - & - & III \\
\hline $\begin{array}{l}\text { Hymenophyllum pulchellum Schldl. \& } \\
\text { Cham }\end{array}$ & Leaf/Stem (Rhizome) & $\begin{array}{l}\text { Globoid/Amorphous } \\
\text { (grouped) }\end{array}$ & Present & II, III \\
\hline $\begin{array}{l}\text { Hymenophyllum rufum Fée } * \\
\text { Polypodiaceae }\end{array}$ & Leaf/Stem (Rhizome) & Lenticular & Present & II \\
\hline $\begin{array}{l}\text { Campyloneurum nitidum (Kaulf.) C. } \\
\text { Presl }\end{array}$ & Leaf & Lenticular & Absent & I \\
\hline Niphidium crassifolium (L.) Lellinger & Leaf & Clavate & Absent & I \\
\hline $\begin{array}{l}\text { Pleopeltis hirsutissima (Raddi) de la } \\
\text { sota }\end{array}$ & Leaf & Globoid & Present & I \\
\hline
\end{tabular}

Sites: I = National Forest of São Francisco de Paula, Rio Grande do Sul State; II = A particular Forest fragment in Rio Grande do Sul State; III = Serra da Bocaína National Park, São Paulo State; IV = A particular Forest fragment in Santa Catarina State; and V = Ibitipoca State Park, Santa Rita do Ibitipoca, Minas Gerais. *Ferns recorded as gall host for the first time.
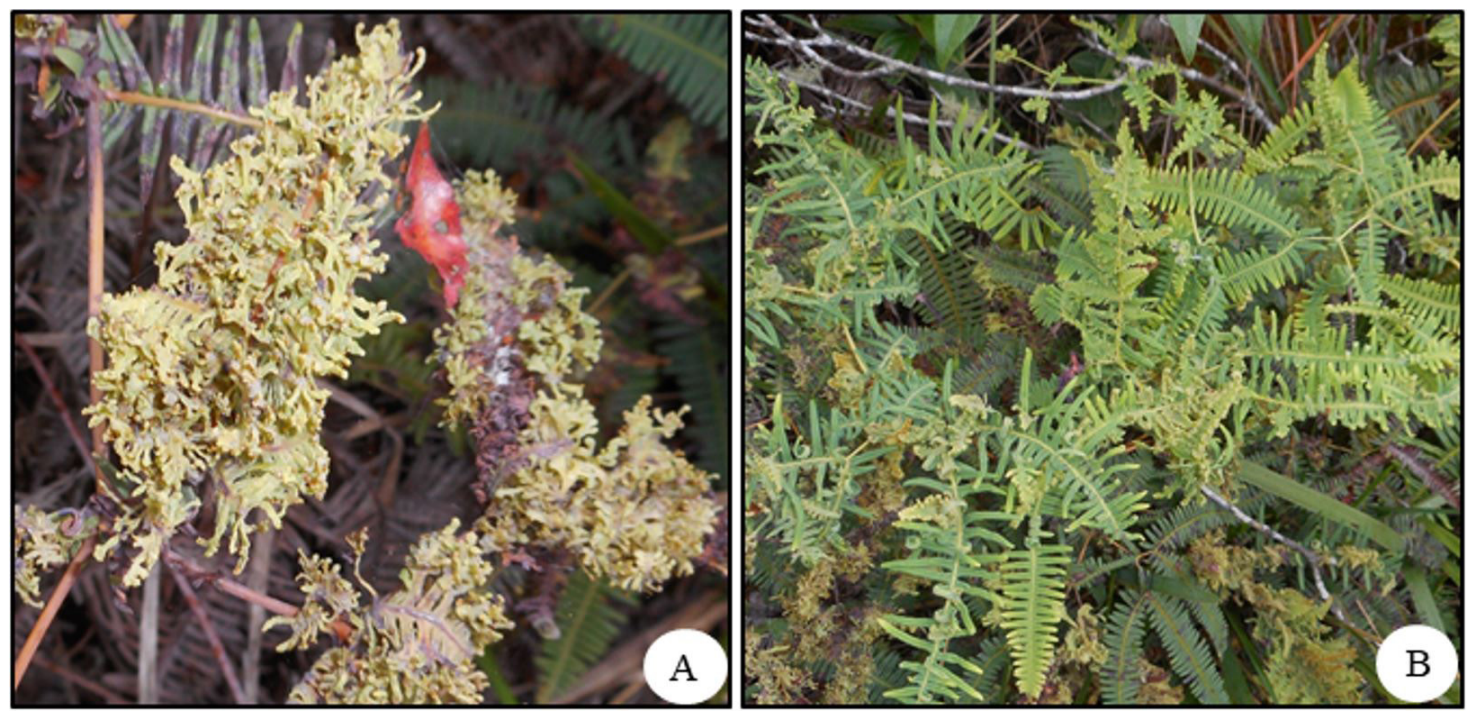

Figure 2. Galls on Glaicheniaceae family. Dicranopteris rufinervis, (A, B) leaf gall. 
State, Brazil. The segments are wider and thicker than normal leaves, and more intensely divided (Figure 1 and 2).

The trichomes were present in H. pulchellum, D. nervosa, D. rufinervis and P. hirsutissima (Table 1). The presence of trichomes in galls may have two implications, the first related to the protection of the galler against parasitoids and/or small sucking herbivores (Fernandes et al., 1987), and the second related to water control and maintenance
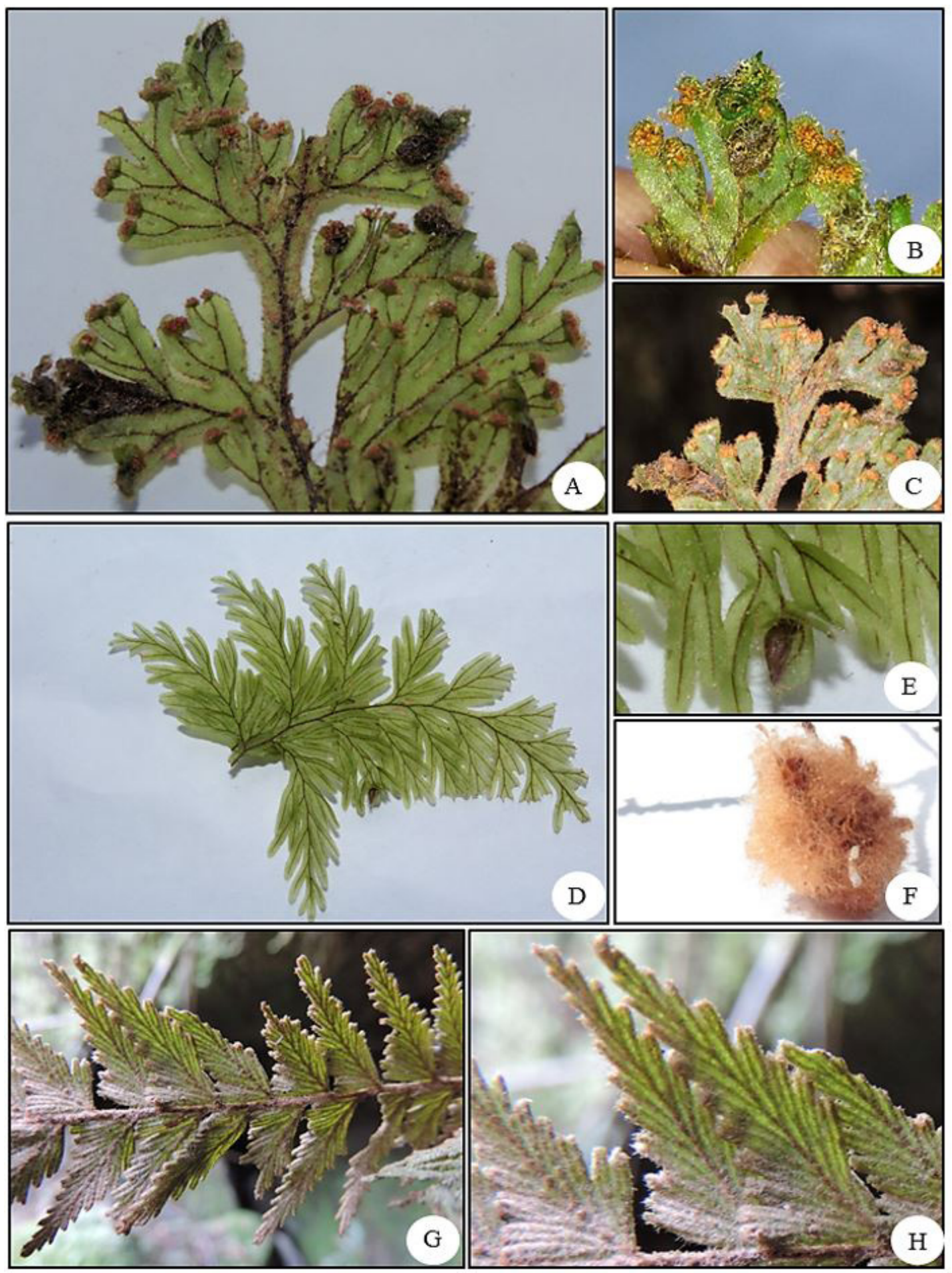

Figure 3. Galls on Hymenophyllaceae family. Hymenophyllum hirsutum, (A-E) leaf gall and (F) stem gall. Hymenophyllum plumosum; $(\mathrm{G}, \mathrm{H})$ leaf gall. 
of the internal temperature (Stone and Schönrogge, 2003). The gall morphotypes were variable and included lenticular (three morphotypes), globoid (two), "Witches' broom", completely amorphous (three), and clavate (one) shapes (Table 1). Additionally, globoid galls in H. pulchellum
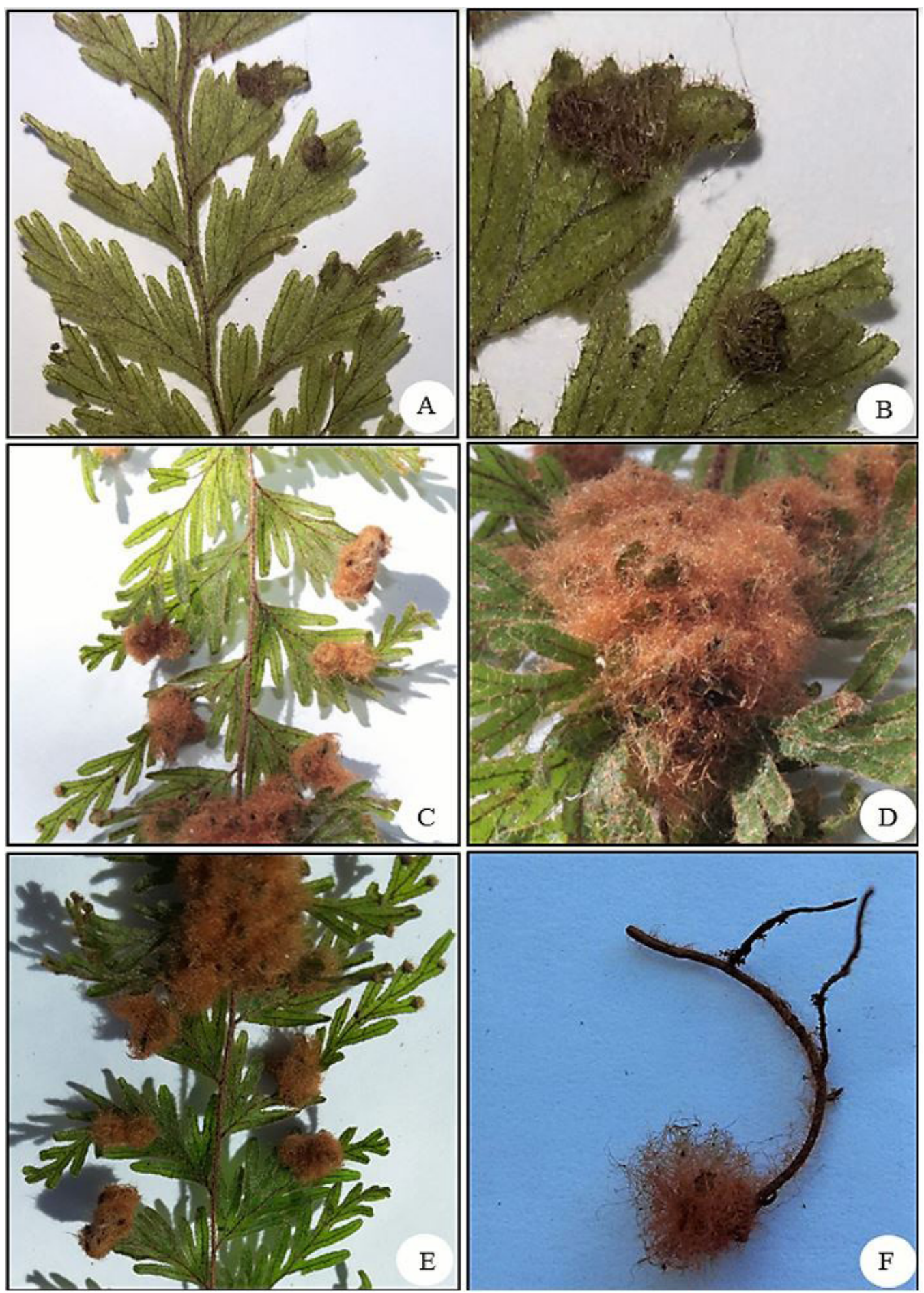

Figure 4. Galls on Hymenophyllaceae family. Hymenophyllum rufum, (A, B) leaf gall. Hymenophyllum pulchellum; (C-E) leaf gall; and (F) stem gall. 

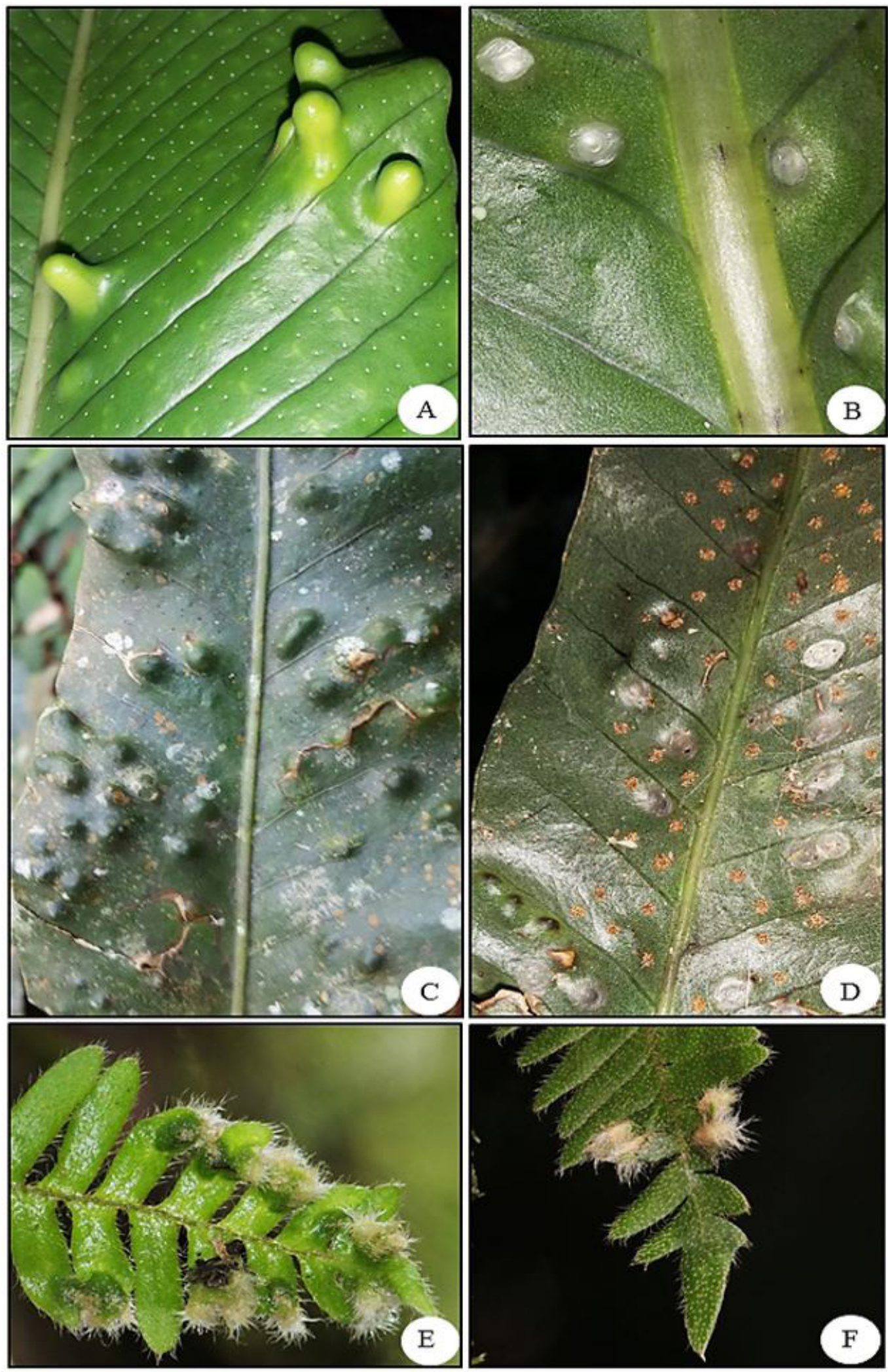

Figure 5. Leaf galls on Polypodiaceae family. Niphidium crassifolium, (A) adaxial side of the leaf and (B) abaxial side of the leaf. Campyloneurum nitidum; (C) adaxial side of the leaf and (D) abaxial side of the leaf. Pleopeltis hirsutissima; (E, F) both on the adaxial side of the leaf. 
and Maia, 2018 for more details). Houard (1933) reports Diptera species as gallers of H. hirsutum and H. pulchellum. Santos and Maia (2018) suggested mites as inducers of the "witches' broom" galls on $D$. flexuosa, an assumption extended to $D$. nervosa and $D$. rufinervis. Efforts must be directed to identify all these organisms.

The list of fern species hosting galling agents presented here, including four new records of galls, increases the knowledge of the richness of gall-inducing herbivores in ferns. It also shows the high potential of new interactions in fern lineages in unexplored sites. Results as these come to change the rather widespread thought that ferns do not have interactions with herbivores. As the knowledge on host plant species is fundamental for forthcoming studies (Araújo et al., 2015), we encourage descriptions of the inducing species, and biogeographic and ecological approaches of ferns. Future histological studies aiming to understand the changes caused by gallers in those plants, and comparisons with the available information about galls in angiosperms are also necessary. Finally, we highlight that Brazil may be at the forefront of the knowledge about interactions between ferns and gall inducers provided sampling efforts in different ecosystems are undertaken (e.g. Amazonian, Cerrado and Caatinga domains) as well as teamwork among botanists, ecologists and entomologists.

\section{Acknowledgements}

The authors are grateful to the University of Caxias do Sul (UCS) and FEEVALE University for permitting the use of their facilities. This study was financed in part by Coordination for the Improvement of Higher Education Personnel (CAPES) financial code-001 for to L.V.Lima (88887.19244/2018-00) and V. L. Silva (88887.146950/2017-00, and Postdoctoral scholarship CAPES $n^{\circ}$. 1805977). J. L. Schmitt would like to thank the National Council for Scientific and Technological Development (CNPq) for the financial support provided (PQ-308926/2017-0). M. G. Santos thanks the CNPq (PQ-308045/2017-3), Carlos Chagas Filho Research Support Foundation of Rio de Janeiro state (FAPERJ E-26/203.236/2017) and the Scientific, Technical and Artistic Production Incentive Program (PROCIENCIA) of Rio de Janeiro State University (UERJ) for financial support.

\section{References}

ARAÚJO, W., PORFÍRIO JÚNIOR, E., RIBEIRO, B., SILVA, T., SILVA, E., GUILHERME, F., SCARELI-SANTOS, C. and SANTOS, B., 2015. Checklist of host plants of insect galls in the state of Goiás in the Midwest Region of Brazil. Biodiversity Data Journal, vol. 3, no. 3, pp. e6835. http://dx.doi.org/10.3897/ BDJ.3.e6835. PMid:26696767.
CARVALHO-FERNANDES, S.P., ALMEIDA-CORTEZ, J.S. and FERREIRA, A.L.N., 2012. Riqueza de galhas entomógenas em áreas antropizadas e preservadas de Caatinga. Revista Árvore, vol. 36, no. 2, pp. 269-277. http://dx.doi.org/10.1590/S010067622012000200008

FERNANDES, G.W., MARTINS, R.P. and TAMEIRÃONETO, E., 1987. Food web relationship involving Anadiplosis sp. galls (Diptera: Cecidomyiidae) on Machaerium aculeatum (Leguminosae). Brazilian Journal of Botany, vol. 10, pp. 117-132.

GONZATTI, F. and WINDISCH, P.G., 2018. Flora do Espírito Santo: Hymenophyllum (Hymenophyllaceae). Rodriguésia, vol. 69, no. 2, pp. 611-629. http://dx.doi.org/10.1590/2175-7860201869225.

HOUARD, C., 1933. Les zoocécidies des plantes de L'Amérique du Sud et de L'Amérique Centrale. Paris: Hermann et Cie. 549 p.

ISAIAS, R.M.S., CARNEIRO, R., OLIVEIRA, D.C. and SANTOS, J.C., 2013. Illustrated and annotated checklist of Brazilian gall morphotypes. Neotropical Entomology, vol. 42, no. 3, pp. 230-239. http://dx.doi.org/10.1007/s13744-013-01157. PMid:23949804.

KRAUS, J.E., MONTENEGRO, G. and KIM, A.J., 1993. Morphological studies on entomogenous stem galls of Microgramma squamulosa (Kauf.) Sota (Polypodiaceae). American Fern Journal, vol. 83, no. 4, pp. 120-128. http://dx.doi.org/10.2307/1547588.

MAIA, V.C. and OLIVEIRA, J.C., 2010. Insect galls of the Reserva Biológica Estadual da Praia do Sul (Ilha Grande, Angra dos Reis, RJ). Biota Neotropica, vol. 10, no. 4, pp. 227-237. http:// dx.doi.org/10.1590/S1676-06032010000400028.

MAIA, V.C. and SANTOS, M.G., 2011. A new genus and species of gall midge (Diptera, Cecidomyiidae) associated with Microgramma vacciniifolia (Langsd. \& Fisch.) Copel. (Polypodiaceae) from Brazil. Revista Brasileira de Entomologia, vol. 55, no. 1, pp. 40-44. http://dx.doi.org/10.1590/S0085-56262011000100008.

MAIA, V.C. and SANTOS, M.G., 2015. Record of insects in two fern species of the genus Microgramma (Polypodiaceae) in the Atlantic Rain Forest, Rio de Janeiro state, Brazil. Brazilian Journal of Biology $=$ Revista Brasileira de Biologia, vol. 75, no. 4, suppl. 1, pp. 253-254. http://dx.doi.org/10.1590/15196984.11114. PMid:26602333.

MANI, M.S., 1964. Ecology of plant galls. The Hague: Junk. 434 p. http://dx.doi.org/10.1007/978-94-017-6230-4.

PEEL, M.C., FINLAYSON, B.L. and MCMAHON, T.A., 2007. Updated world map of the Köppen-Geiger climate classification. Hydrology and Earth System Sciences, vol. 11, no. 5, pp. 16331644. http://dx.doi.org/10.5194/hess-11-1633-2007.

RAMAN, A., 2007. Insect-induced plant galls of India: unresolved questions. Current Science, vol. 92, no. 6, pp. 748-757.

SANTOS, M.G. and MAIA, V.C., 2018. A synopsis of fern galls in Brazil. Biota Neotropica, vol. 18, no. 3, pp. e20180513. http:// dx.doi.org/10.1590/1676-0611-bn-2018-0513.

STONE, G.N. and SCHÖNROGGE, K., 2003. The adaptive significance of insect gall morphology. Trends in Ecology \& Evolution, vol. 18, no. 10, pp. 512-522. http://dx.doi.org/10.1016/ S0169-5347(03)00247-7. 